\title{
Oxidant and antioxidant status of police officer in the city and rural area
}

\author{
F.D. Suyatna ${ }^{*}$, Priyanto $\$$, J. Istiantoro ${ }^{*}$, M. Sadikin ${ }^{\#}$
}

\begin{abstract}
Abstrak
Penelitian ini dirancang untuk menyelidiki perubahan biokimia pada manusia oleh akumulasi radikal bebas karena polusi udara. Penelitian dilakukan terhadap 60 polisi desa yang terdiri atas 30 bukan perokok (kelompok I) dan 30 perokok (kelompok II); 30 polisi administratif perokok di Jakarta (kelompok III) dan 30 polisi lalu lintas perokok di Jakarta (kelompok IV). Hasil penelitian menunjukkan bahwa kadar malondialdehid plasma (MDA) kelompok I, II, III, dan IV adalah : $3.34 \pm 0.81 \mu \mathrm{mol} / \mathrm{l} ; 4.28 \pm 0.77 \mu \mathrm{mol} /$; $5.20 \pm 0.66 \mu \mathrm{mol} / \mathrm{l}$ dan $5.12 \pm 0.78 \mu \mathrm{mol} / \mathrm{l}$ yang secara statistik berbeda satu sama lainnya $(p<0.01)$, kecuali antar kelompok III dan IV. Aktivitas superoksida dismutase (SOD) dari kelompok-kelompok tersebut adalah : $16.75 \pm 9.80 \mathrm{U} / \mathrm{mg}$ protein; $22.83 \pm 6.82 \mathrm{U} / \mathrm{mg}$ protein; $26.10 \pm 8.50 \mathrm{U} / \mathrm{mg}$ protein dan $26.90 \pm 9.34 \mathrm{U} / \mathrm{mg}$ protein, yang berbeda secara statistik antara kelompok I terhadap kelompok lainnya $(p<0.05)$. Aktivitas katalase kelompok-kelompok tersebut adalah : $106.25 \pm 47.47$ U/mg protein; $118.84 \pm 42.73$ U/mg protein; $119.83 \pm 35.35 \mathrm{U} / \mathrm{mg}$ protein dan $145.57 \pm 61.85 \mathrm{U} / \mathrm{mg}$ protein. Terdapat perbedaan yang secara statistik bermakna antara kelompok I dan IV. Pemberian vitamin C (500 mg) dan E (300 mg) per hari selama 30 hari pada polisi dengan tingkat stres oksidasi yang tinggi menurunkan aktivitas SOD dari $27.34 \pm 10.05 \mathrm{U} / \mathrm{mg}$ protein menjadi $16.91 \pm 6.51 \mathrm{U} / \mathrm{mg}$ protein $(p<0.05)$ dan katalase dari $134.29 \pm 53.28 \mathrm{U} / \mathrm{mg}$ protein menjadi $67.07 \pm 25.26 \mathrm{U} / \mathrm{mg}$ protein $(p<0.05)$. Penelitian ini menunjukkan bahwa status oksidasi polisi kota lebih tinggi daripada polisi desa dan kombinasi vitamin $C$ dan E dapat menurunkan sebagian stres oksidasi tersebut. (Med J Indones 2004; 13: 77-80)
\end{abstract}

\begin{abstract}
This study was designed to investigate the biochemical alteration in human caused by free radical accumulation due to air pollution. The policemen recruited were 60 country policemen consisting of 30 non smokers (group I) and 30 smokers (group II); 30 smoking policemen with administrative work in Jakarta (group III) and 30 smoking traffic policemen from Jakarta (group IV). Our results show that the plasma malondialdehyde (MDA) contents of groups I, II, III, IV, respectively were : $3.34 \pm 0.81$ umol/l; $4.28 \pm$ $0.77 \mathrm{umol} / \mathrm{l} ; 5.20 \pm 0.66 \mathrm{umol} / \mathrm{l}$ and $5.12 \pm 0.78$ umol/l which were statistically different $(p<0.01)$ among each others, except between groups III and IV. The activity of superoxide dismutase (SOD) of the groups respectively, were: $16.75 \pm 9.80 \mathrm{U} / \mathrm{mg}$ protein; $22.83 \pm 6.82 \mathrm{U} / \mathrm{mg}$ protein; $26.10 \pm 8.50 \mathrm{U} / \mathrm{mg}$ protein and $26.90 \pm 9.34 \mathrm{U} / \mathrm{mg}$ protein, which were statistically different $(p<0.05)$ between group I vs the other groups. The catalase activity of the groups respectively were : $106.25 \pm 47.47 \mathrm{U} / \mathrm{mg} \mathrm{protein} ; 118.84 \pm$ $42.73 \mathrm{U} / \mathrm{mg}$ protein; $119.83 \pm 35.35 \mathrm{U} / \mathrm{mg}$ protein and $145.57 \pm 61.85 \mathrm{U} / \mathrm{mg}$ protein. The statistical difference $(p<0.05)$ was found between group I \& IV. Administration of vitamins $C(500 \mathrm{mg})$ and $E(300 \mathrm{mg})$ daily for 30 days to the policemen with high oxidant stress caused a decreased in the activities of SOD from $27.34 \pm 10.05 \mathrm{U} / \mathrm{mg}$ protein to $16.91 \pm 6.51 \mathrm{U} / \mathrm{mg}$ protein $(\mathrm{p}<0.05)$ and catalase from $134.29 \pm 53.28 \mathrm{U} / \mathrm{mg}$ protein to $67.07 \pm 25.26 \mathrm{U} / \mathrm{mg}$ protein $(p<0.05)$. This study shows us that the oxidant status of city policemen was higher than that of rural policemen and that a combination of vitamins $C \& E$ could reduce the oxidant stress to a certain extent. (Med J Indones 2004; 13: 77-80)
\end{abstract}

Keywords: malondialdehyde, superoxide dismutase, catalase, population study.

Air pollutants have been a major problem in big cities. Jakarta which inhabited by 12 million people is

\footnotetext{
* Department of Pharmacology, Faculty of Medicine, University of Indonesia, Jakarta, Indonesia

${ }^{\$}$ Department of Biochemistry, Faculty of Medicine, University of Indonesia, Jakarta, Indonesia

${ }^{\text {\# }}$ The Laboratory of Police Health, Police Headquater, Jakarta, Indonesia
}

typically interested to be investigated. The great number of vehicles and some industrial areas around the city become the main source of air pollutants. In addition to that smoking habits may add oxidative stress to the people. Air pollutants have been associated with various free radical-based diseases, such as pulmonary, metabolic and immunologic diseases and cancer. ${ }^{1}$ 
The purpose of the present study is to investigate the oxidant and antioxidant status of policemen, a population fraction whose profession is closely related to air pollution.

\section{METHODS}

There were 120 policemen recruited in the study : 60 country policemen from a rural area at Sukabumi, West Java, consisting of 30 smokers and 30 non smokers; 30 policemen, smokers, whose activities were administrative in the office and 30 traffic policemen, smokers from Jakarta. The policemen from Jakarta smoked at least 13 cigarettes per day; the administrative policemen worked at the National Police Headquarter, Jakarta and the traffic policemen had been working as field policemen for at least the last 6 months period. The policemen from Sukabumi were from the Institute of Education for Police (SECAPA). Sukabumi is a small town in rural area of West Java, with a small number of vehicles.

All subjects were males of 20-48 years old, healthy, not under any medical treatment, not consumed any food supplement or certain diet within the last 4 weeks before the study began and signed a written informed consent. The study had been approved by heads of the National Police Hospital Jakarta, the Sukabumi Police Hospital and, Health Division of National Police Headquarter, Jakarta.

In the first phase, the plasma contents of malondialdehyde (MDA), erythrocyte superoxide dismutase (SOD) and catalase (CAT), were determined prior to vitamin $\mathrm{E}$ administration to obtain the baseline data. The subjects with an increased oxidative stress as shown by high contents of MDA, SOD, CAT were recruited for the second phase of study.

There were 30 subjects with high oxidative stress identified; these subjects were given a combination of vitamin $\mathrm{E}(300 \mathrm{mg})$ and vitamin $\mathrm{C}(500 \mathrm{mg})$ per day for 1 month. After treatment the biochemical parameters were again determined.

SOD was determined according to Misra et $\mathrm{al}^{2}$ using epinephrine as a substrate, catalase as described by Beers and Sizer, ${ }^{3}$ MDA as described by Wills ${ }^{4}$ and protein as described by Peterson. ${ }^{5}$

The data obtained were analyzed using one-way ANOVA followed by Tukey test if the data were normally and homogeneously distributed or by Kruskal-Wallis method if the data were not normally distributed.

\section{Drugs and chemicals}

D.L epinephrine, thiobarbituric acid, albumin were purchased from Sigma Co. St. Louis, USA. Malondialdehyde was from TCI (Japan). Chemicals for buffer preparation were from E. Merck, Darmstadt, Germany. Vitamin E (D.L- $\alpha$-tocopheryl nicotinate) and $\mathrm{C}$ were a generous gift from PT Eisai Indonesia.

\section{RESULTS}

Plasma MDA contents in the 4 groups are shown in Table 1. This table shows that the plasma MDA content of country policemen either non smokers (Group I) or smokers (Group II) was significantly lower $(p<0.05)$ than that of administrative policemen (Group III) and traffic policemen of Jakarta (Group IV). In addition to that the MDA content of non smokers country policemen was significantly lower than that of the smoker ones $(\mathrm{p}<0.05)$. As can be seen from the table, the SOD activity in Group I was significantly lower than that of the other groups $(\mathrm{p}<$ 0.05 ) and that there was no difference in SOD activity among Groups II, III and IV. A similar trend was also seen in which low activity of catalase was found in country policemen if compared with that of the policemen from Jakarta. The activity of catalase in Group I was significantly lower than that of Group IV.

Table 1. Plasma malondialdehyde contents, superoxide dismutase and catalase activities in policemen

\begin{tabular}{cccc}
\hline Group & $\begin{array}{c}\text { Malondialdehyde } \\
\text { (umol/l) }\end{array}$ & $\begin{array}{c}\text { Superoxide dismutase } \\
\text { (U/mg protein) }\end{array}$ & $\begin{array}{c}\text { Catalase } \\
\text { (U/mg protein })\end{array}$ \\
\hline I & $3.34 \pm 0.81^{1}$ & $16.75 \pm 9.80^{1}$ & $106.25 \pm 47.47^{3}$ \\
II & $4.28 \pm 0.77^{2}$ & $22.83+6.82$ & $118.84 \pm 42.73$ \\
III & $5.20 \pm 0.66$ & $26.10 \pm 8.50$ & $119.83 \pm 35.35$ \\
IV & $5.12 \pm 0.78$ & $26.90 \pm 9.34$ & $145.57 \pm 61.85$ \\
\hline
\end{tabular}

Statistically different $(\mathrm{p}<0.05)$

${ }^{1}$ Between Group I and others (Groups II, III, IV)

${ }^{2}$ Between Group II and Groups III, IV

${ }^{3}$ Between Group I and IV 
In order to investigate whether antioxidants might have some beneficial effects, 30 policemen from Jakarta with high oxidative stress (high MDA, SOD and catalase) were selected out of the studied samples and treated with a combination of vitamin E $(300 \mathrm{mg})$ and C $(500 \mathrm{mg})$ daily for 1 month. Table 2 shows that after 1 month of the vitamins consumption, SOD and catalase activities were significantly lower than that before treatment $(\mathrm{p}<0.05)$. The MDA contents were also lower when compared with those before the administration of vitamins, although it is not statistically significant. There was no adverse effect of the combination of vitamin $\mathrm{E}$ and $\mathrm{C}$ reported by the volunteers during observation period.

Table 2. Plasma malondialdehyde contents, superoxide dismutase and catalase activities in policemen with high risk of oxidative stress before and after treatment with vitamin E (300 mg) and vitamin $\mathrm{C}(500 \mathrm{mg})$ once daily for $1 \mathrm{month}$

\begin{tabular}{ccc}
\hline \multicolumn{1}{c}{ Parameters } & Before & $\begin{array}{c}\text { After treatment } \\
\text { with a combination } \\
\text { of vitamins E \& C }\end{array}$ \\
\hline $\begin{array}{l}\text { Plasma malondialdehyde } \\
\text { (umol/l) }\end{array}$ & $5.06 \pm 0.90$ & $4.90 \pm 1.02$ \\
$\begin{array}{l}\text { Superoxide dismutase } \\
\text { (U/mg protein) }\end{array}$ & $27.34 \pm 10.05$ & $16.91 \pm 6.51^{*}$ \\
Catalase (U/mg protein) & $134.29 \pm 53.28$ & $62.07 \pm 25.26^{*}$ \\
\hline
\end{tabular}

* Significantly different $(\mathrm{p}<0.05)$ in comparison with the values before treatment with a combination of vitamin E \& C

\section{DISCUSSION}

Free radicals have been incriminated in the development of various degenerative diseases. ${ }^{1,6}$ In big cities like Jakarta, pollutant burden has become a great problem for its inhabitants. The components of air pollutants consists of ozone, $\mathrm{NO}, \mathrm{NO}_{2}, \mathrm{SO}_{2}, \mathrm{CO}$ and hydrocarbons. The toxic effects of pollutants have begun at an early age and will manifest in adulthood. In mice, depending on the duration of exposure, $\mathrm{NO}_{2}$ or $\mathrm{O}_{3}$ will cause a series of biological derangements from increased lipid peroxidation to the development of defined bronchitis or emphysema. ${ }^{7}$

The presence of increased concentrations of toxic gases in Jakarta is aggravated by the presence of lead in exhausted gases expelled by vehicles. Jakarta is a typical tropical city with hot weather and high humidity. Although its sky is somewhat clear during rainy season and windy condition, most of the time our long distance visibility is limited by the grey smoke covering the atmosphere, suggesting that air pollution has taken place.

In the present study we investigated the effects of air pollution to the oxidant-antioxidant status of urban and rural policemen, a segment of population which is highly exposed to noxious gases in the fields. The effects of smoking was studied by comparing the non smoker vs smoker policemen of the rural area. Our results show that the MDA and SOD contents of the non smoking policemen were significantly lower than those of the smoking policemen, whereas catalase activities remained at the same values. These data demonstrate the harmful effects of smoking to the antioxidant defense mechanism of the body. Our study confirm the results of Reddy et $\mathrm{al}^{8}$ who investigated the relationship of oxidant stress between the city and rural inhabitants. In our study, however, the catalase activity was not increased in the smoking policemen. There are several possibilities that may explain this. Firstly, it might be because that the oxidant burden in Jakarta was not heavy enough to increase significantly the activity of catalase, an enzyme that converts the $\mathrm{H}_{2} \mathrm{O}_{2}$ produced by SOD to $\mathrm{H} 2 \mathrm{O}$. Secondly, excess of $\mathrm{H}_{2} \mathrm{O}_{2}$ might be neutralized primarily by peroxidases like glutathione peroxidase.

In their study on the effects of pollutant on antioxidant capacity and degree of peroxidation in Mexico City, Medina - Navarro et al ${ }^{9}$ showed an early increase of SOD in volunteers living for 4 months in the city, followed by a decrease of the enzyme's activity. On the other hand, serum MDA level decreased at the end of the study. The authors suggested that after 4 months of stay in Mexico City, there were adaptive changes occur in the volunteers in which the rate of SOD degradation exceeds its rate of synthesis and that some serum antioxidative defense mechanisms increased causing serum MDA to decrease.

If the parameters studied can be considered as valid, then the pollution burden in Jakarta might be less severe than that in Mexico City, since in the present study we found an increase rather than a decrease in SOD activity.

Comparative data in oxidant - antioxidant status between that of smoking rural policemen vs smoking administrative urban policemen showed that the serum MDA levels of the first group were significantly lower than that of the latter and that SOD and catalase activities were not significantly different 
between both groups. These data indicate that polluted air in big cities has additional effect in increasing oxidant burden already exist upon smoking. This suggestion is supported by the similar oxidantantioxidant status in terms of MDA contents, SOD and catalase activities of smoking urban police, the administrative vs the traffic one. The harmful effects of polluted air mediated by free radical production has been associated with various degenerative diseases including cancer generation. Our study strongly support this hypothesis and that the administration of antioxidant vitamins might have some beneficial effects on the reversal of biochemical alteration caused by free radicals.

\section{REFERENCES}

1. Cross CE, Halliwell B, Borish ET, Pryor WA, Ames BN, Saul RL, McCord JM, Harman D. Oxygen radicals and human disease. Annals Internal Med 1987; 107:526-45.

2. Misra HP, Fridovich L. The role of superoxide dismutase anion in the auto-oxidation of epinephrine and a simple assay for superoxide dismutase. J Biol Chem 1972; 247:3170-3.

3. Beers RF, Sizer IW. A spectrometric method for measuring the breakdown of hydrogen peroxide by catalase. J Biol Chem 1952;195: 133-40.

4. Wills ED. Evaluation of lipid peroxidation in lipids and biological membranes. In: K Snell and B Mullock (eds), Biochemical Toxicology. Section 6, IRL Press, Oxford, Washington DC, 1987, pp 138-41.

5. Peterson GL. A simplification of the protein assay method of Lowry et al. which is more generally applicable. Anal Biochem 1997; 83:346-56.

6. Halliwell B, Gutteridge JMC. Air pollutants. In: Free radicals in Biology and Medicine. Section 8, Oxford University Press, 1999, p 577-91.

7. Menzel DB. Antioxidants in lung disease. Toxicol Ind Health, 1993; 9:323-6.

8. Reddy KK, Ramamurthy R, Somasekarariah BV, Kumara TP, Rao P. Free radical and antioxidant status in urban and rural Tirupati men : Interaction with nutrient intake, substance abuse, obesity and body fat distribution. Asia Pacific J Clin Nutr 1977; 6:296-311.

9. Medina-Navarro R, Lifshitz A, Wacher N, Hicks JJ. Changes in human serum antioxidant capacity and peroxidation after four months of exposure to air pollutants. Arch Med Res 1996; 28:205-8. 